\title{
Transforming the Fashion Industry by: The Evolution of Design \& Merchandising Education
}

\author{
Chris Baeza \\ Drexel University \\ Elizabeth Quinn \\ MS Fashion Design \\ Drexel University
}

How do we prepare students for the fashion industry in the face of an ethical awakening when issues of climate change are complicated by political turmoil, social injustice, and food insecurity, where advances in technology ignite concerns over surveillance, data privacy, equity, and dependence? What if those working in the fashion system had a deeper sense of responsibility for their product creation? As the fashion industry shifts, awareness of the ethical implications has become a necessity and responsibility not only for industry professionals but for educators who are teaching the next generation. Fashion design and merchandising curricula may skim the surface of ethical design and strategy but often falls short on how to integrate ethical decision-making into coursework.

The authors seek to answer this overarching question: are students who study fashion design and merchandising better prepared after graduation when ethics and entrepreneurship are an integral part of their curricula?

Keywords: ethics, fashion design, fashion merchandising, social entrepreneurship, circular economy, sustainable fashion

\section{INTRODUCTION}

As design practices shift, awareness of the ethical implications has become a necessity and responsibility not only for design professionals but also for design educators who are teaching the next generation. Design and merchandising curricula mayskim the surface of ethical practices, but often falls short on integrating ethical decision-making into design processes and business practices.

Based on individual research, literature reviews, interviews with industry leaders, and various adjustments to course design, this paper explores the exchange of ideas and the intersection of the fields of ethics and entrepreneurship in design and merchandising education and asserts the importance of this exchange regarding how design problems are understood, how solutions will be executed, and how higher education develops the next generation of design and merchandising professionals. The practice of designing a cohesive, saleable and sustainable collection goes far beyond the study and experimentation 
with color and concept forecasting and assortment planning. Rather, truly sustainable collections must carefully analyze the design phase in the produce life cycle for positive ethical and ecological impacts.

Attesting to this notion, Lewis Perkins, President of the Apparel Impact Institute, noted that data from the Higg Index shows a need for brands to prioritize a material strategy which happens during the design phase. Furthermore, Amy Hall, Vice President of Eileen Fisher, shared that systems mapping revealed the impacts design and merchandising decisions had on the manufacturing process and the brand's overall carbon footprint. Both conversations with industry leaders highlight the importance of analyzing decisions made during the design phase in order to ensure a more eco-ethical product offering and organizational structure. Concurrently, these discussions present a need for students to work with and in the industry in order to better understand how coursework is connects to practical application in the industry.

Are design and merchandising programs preparing students to be responsible young professionals? Students studying fashion design are trained in technical garment and pattern making skills alongside color and concept research for collection designing and development. And students studying merchandising are trained to curate balanced product assortments to maximize profit. Does design and merchandising education adequately explore the range of problems within the textile and fashion industry and allow students to consider what "better" actually is? Matt Manos, the founder of verynice, explains, "A social entrepreneur is a designer of business whose intentions are not in capital gain, but instead in the advancement of the greater good of society." (Matthew Manos, n.d.) Recognized as one of the 100 most influential creatives working today by HOW Magazine, Matthew Manos is also a professor who focuses on social impact. The formula is: business + design + ethics $($ greater good) $=$ social enterprise. Muhammad Yunus, the Bangladeshi economist, microfinancing pioneer, and founder of the grassroots Grameen Bank, was quoted in The Guardian as saying, "We are all entrepreneurs." (Cosic, 2017) He believes in social enterprises that adopt entrepreneurial market-based approaches to create social and environmental impact. Should entrepreneurship be an integral part of design and merchandising curricula?

The authors seek to answer these overarching questions: Are designers better prepared after graduation when ethics and entrepreneurship are an integral part of design and merchandising curricula? How can the examination of design phase practices allow students space to conceptualize, explore, and critique design ideas through an ethical lens?

\section{EXPERIENCE, ETHICS, AND ENTREPRENEURSHIP}

With climate change and social injustice crippling the planet, the motivation to instil ecological and ethical values in the future creative workforce is clear; the means of doing so, however, can be an overwhelming task. The United Nation's Decade of Education for Sustainable Development outlined clear direction more than fifteen years ago on how the structure of higher education should take a more holistic approach to graduating critical thinkers who are entering industry in an age of continual environmental and social uncertainty. UNESCO asserted that "Higher education should emphasize experiential, inquiry-based, problem-solving, interdisciplinary systems approaches and critical thinking. Curricula need to be developed, including content, materials and tools such as case studies and identification of best practices." (Framework for the UN DESD international implementation scheme, 2006) Given this call to action, shouldn't the responsibility of higher education instructors be to develop creative and critical thinking skills in students to ensure they can meet the demands in ever-changing workplaces? The authors propose that by integrating three key components across curricula as detailed in this section, a more comprehensive approach to fashion education will do just that.

\section{ETHICS IN DESIGN AND MERCHANDISING EDUCATION}

Ethics provides a set of standards for behavior that help guide decision-making. In a sense, ethics is all about making choices and about providing reasons why these choices were made. As a field of study, ethics has a lot of knowledge to offer; however, in discussing sustainable and responsible practices, ethics is an often overlooked yet crucial component. In 2010, John Vucetich and Michael Nelson wrote of the 
significance of ethics, stating that "Without developing the ethical dimension of sustainability, we will never even know what sustainability means, and will therefore be ignorant about how to achieve it... More specifically, sustainability may well be the primary schema for describing and evaluating what it means to be a good person or good society in today's world." (Vucetich and Nelson, 2010) Across university campuses, ethics is taught in a variety of disciplines and often through a theorical lens versus applied. Ethics can be overwhelming for design educators given the existing content requirements. The authors' aim is to make the integration of ethics into design and merchandising curricula assessable. As seen on the "Ethics for Designers" website, Jet Gispen developed a template that introduces the most known theories of normative ethics (virtue, duty, and consequentialism): the study of ethical action. Gispen, like the author's, identified an opportunity for design students to incorporate ethics into the design process. According to Viktor Hiort af Ornäs and Martina Keitsch:

"There are at least two possibilities of integrating ethics in design curriculum: (1) Recognition of ethical dilemmas through informed discourse and (2) intuitive understanding of these dilemmas through reflective practice, or according to Aristotle, 'developing one's moral and intellectual virtues.' The former is discussing moral challenges by identifying, analyzing and assessing ethical problems connected with products and services. The latter is applying ethics in design cases and getting an intuitive understanding of right and wrong" (Keitsch and af Ornäs, 2016)

The Design Ethics Canvas tool (Fig. 1) gave students in a co-taught course title, "Design, Disaster and Impact" the opportunity to more deeply explore the existing design thinking framework. The canvas was adapted from a template developed by Gispen and validated the efficacy of inclusion of applied ethics in the design thinking process. From student interviews after the course, there was an agreement that the ethics canvas offered an active reflected process which yielded a shift in mindset within and outside of the classroom. The authors will purposefully experiment further to use the canvas in design and merchandising courses to create moments of reflection for students to understand the ethical implication of decisions and speculations. 


\section{FIGURE 1 \\ THE DESIGN ETHICS CANVAS}

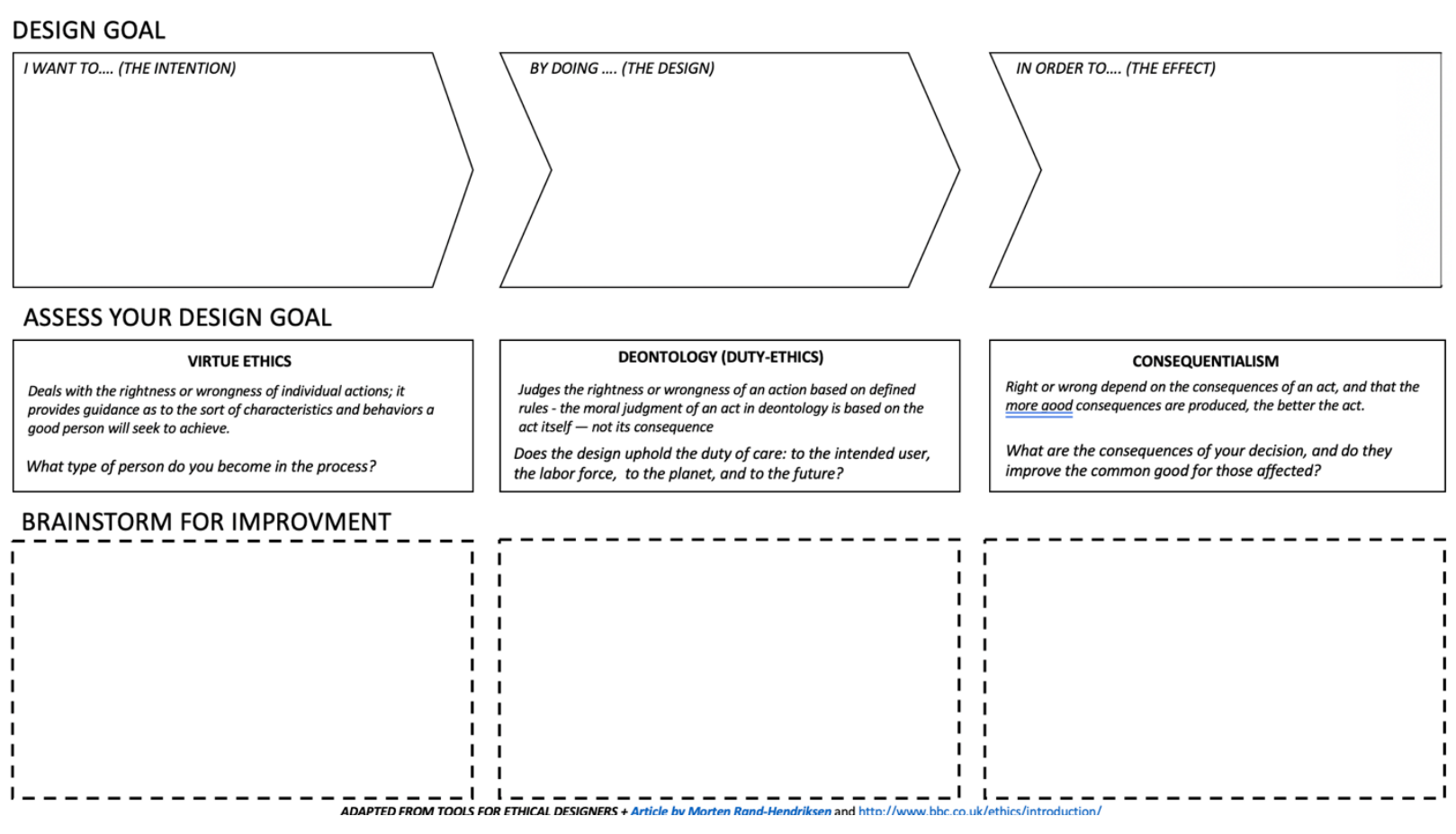

\section{ENTREPRENEURSHIP IN DESIGN AND MERCHANDISING EDUCATION}

Universities have come to understand that the teaching of entrepreneurship is critical to giving students the tools needed to take concepts to market and to compete and perform in today's business environment. However, such courses stand apart from a student's design and merchandising degree.

Entrepreneurship is an act of being an entrepreneur, or "the owner or manager of a business enterprise who, by risk and initiative, attempts to make profits". (Definition of entrepreneur | Dictionary.com, n.d.) Entrepreneurs act as managers and oversee the launch and growth of an enterprise. In the 1930s, economist Joseph Schumpeter shaped our current understanding of entrepreneurship. According to Schumpeter, an entrepreneur is a person who is willing and able to convert a new idea or invention into a successful innovation. In the 2000s, usage of the term "entrepreneurship" expanded to include how and why some individuals identify opportunities, evaluate them as viable, use these opportunities to develop new products or services, launch new firms or industries, and create wealth. There has been a further extension of entrepreneurship from its origin in for-profit businesses to include social entrepreneurship, in which business goals are aligned with social and environmental goals. The landscape of American corporations is changing. As the 21st century unfolds, there has been an increased emphasis on other values and measures for a success of a business, particularly social and environmental concerns. The trend for change has led to the explosive growth of B Corporations, which dates back to 2007. As seen on the website for B corporation, "Certified B Corporations are businesses that meet the highest standards of verified social and environmental performance, public transparency, and legal accountability to balance profit and purpose". (About B Corps | Certified B Corporation, n.d.)

The qualitative evidence by Harvard Business Review authors shows that Certified B firms believe that "the major crises of our time are a result of the way we conduct business", and they became a B Corporation to "join the movement of creating a new economy with a new set of rules" and "redefine the way people perceive success in the business world". (Kim, Karlesky, Myers and Schifeling, 2016) The Ethical Entrepreneurship Canvas tool (Fig. 2) has been used in a co-taught course title, "Design, Disaster and 
Impact" where students not only created novel solutions based upon the project brief, they also developed a market-based solution align with ethical decision making. The canvas was adapted from the business model canvas, the social business model canvas and the B-Corp Assessment Pillars. The authors will purposefully experiment further to use the canvas in design and merchandising courses so students can adopt entrepreneurial market-based approaches to create social and environmental impact.

\section{FIGURE 2 \\ ETHICAL ENTREPRENEURSHIP CANVAS}

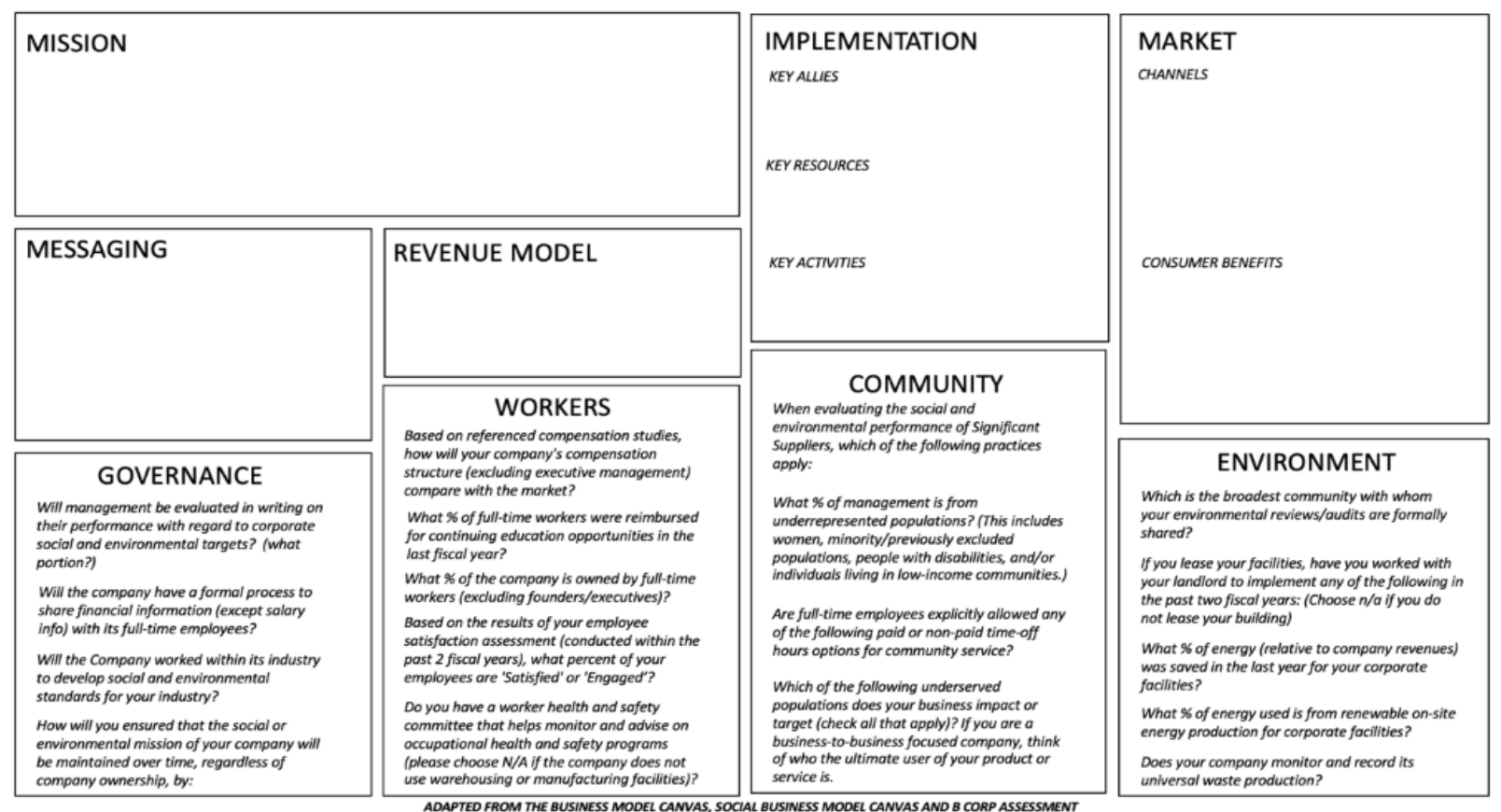

\section{EXPERIENTIAL AND TRANSDISCIPLINARY PEDAGOGY}

There are few universities that have undergone full program restructuring; however, the majority have opted for a simpler approach of adding programs, certificates, and courses that focus on sustainability. While additional points of entry can be beneficial, these are often merely reactive attempts to fill in the voids of existing curricula. A much more in-depth analysis of academia's traditionally structured disciplines is needed to truly educate students in a way that prepares them for the ever-changing world. Victor Papanek, an Australian-American designer and design educator, pinpointed the limitations of pedagogy in modern design curricula when he wrote "The main trouble with design schools seems to be that they teach too much design and not enough about the ecological, social, economic, and political environment in which design takes place". (Papanek, 2016)

While many fashion design programs indeed graduate skilled practitioners of their trade, few focus efforts on the practical and industry application of these skills, especially as they relate to environmental and ethical conditions. Amy Hall, Vice President of Eileen Fisher, shared that there is a need to understand design principles and technical skills on a much higher level than just mastering the techniques. Critical assessments of current fashion design curricula reveal that too often a particular skill set, or design principle is mastered in an isolated setting under ideal conditions, and without consideration for unintended consequences that could and do arise in industry settings. In looking at merchandising curricula, traditional programs focus on the required industry skills with an emphasis on maximizing profits, while well-crafted programs integrate design thinking and a better comprehension of the designer's role in the product life cycle. However, even when this integration occurs, the shortfall remains the same as in design curricula, 
and a much deeper analysis of the design phase practices and consequences is required. These ramifications are far reaching, as evidenced in the varied and significant research studies regarding the apparel industry's negative impact on both people and the planet throughout the product life cycle.

It is now imperative for higher education institutions to adopt opportunities that connects disciplines and establishes creative, collaborative, and real-world learning environments. This notion was highlighted by Richard West in his article entitled Breaking Down Walls to Creativity Through Interdisciplinary Design, wrote "When we are attempting to teach our students how to be creative, interdisciplinary knowledge becomes critical, as new innovations often emerge on the boundaries of disciplines". (West, 2016)

This pedagogical strategy of experiential learning infused with transdisciplinary knowledge and skills will allow students to consider industry challenges, capitalize on their respective talents and create real value which considers people, planet and profit. What approach can be taken within existing course curriculum to immerse students into the fashion industry so they may gain insightful knowledge about environmental and social implications that will have lasting impact on their own design and merchandising practices? The authors will analyze existing frameworks of the fashion design and design and merchandising plans of study within their institution, define critical opportunities for transdisciplinary curricula, and propose a transformative pedagogy. (see Appendix)

\section{Current Program(s) Framework}

Both authors have made significant updates to content within courses each teaches. In addition, one of the authors is a program director for design and merchandising and has worked with all full-time faculty to integrate sustainability and ethical fashion across the existing four-year plan of study, with outcomes of students affecting change within the companies they are employed. It should be noted that the authors are not reporting that the plans of study for each program do not adequately prepare students with industry skills and knowledge - both programs are robust and have rates of $90 \%$ employment upon graduation rather, their research aims to integrate more forward-thinking pedagogy and learning experiences to ensure graduates are better prepared after graduation and have longevity in the textile and fashion industry. The graphic below shows how the existing plans of study for both majors build year over year and the proposed pedagogy for moving forward.

FIGURE 3

TRANSDISCIPLINARY DESIGN AND MERCHANDISING MODEL

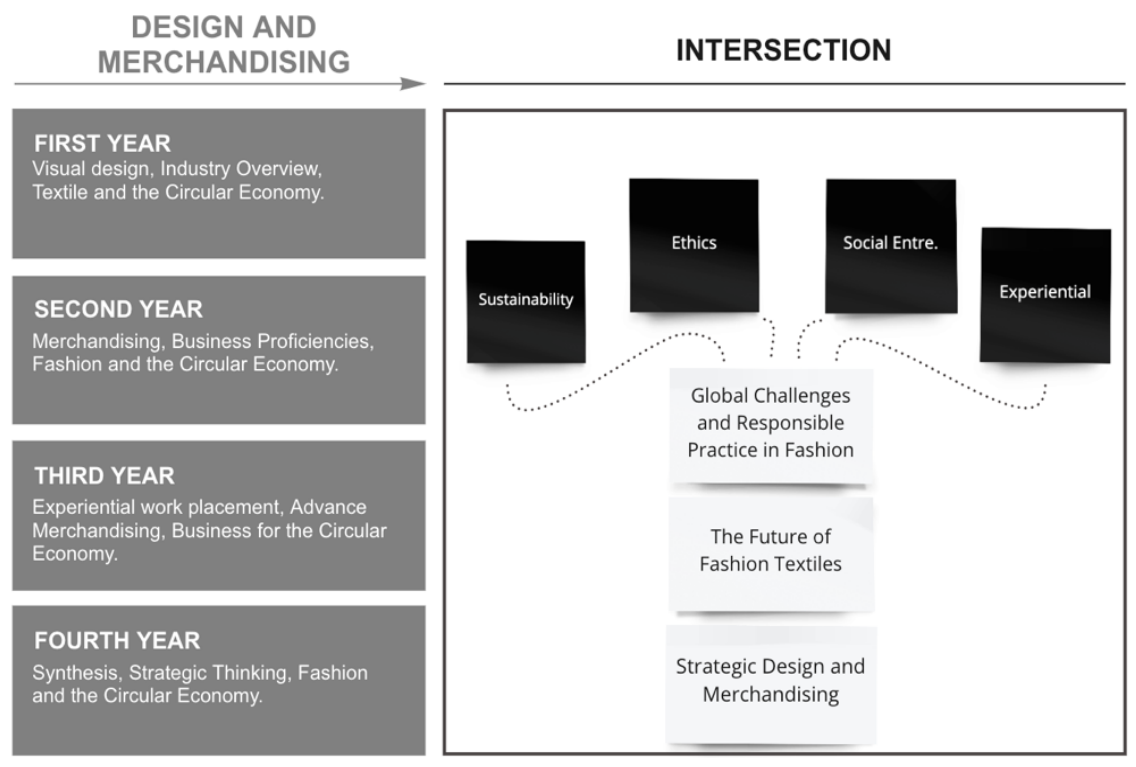

FASHION DESIGN

FIRST YEAR

Visual design, Industry Overview,

Sustainable design solutions.

SECOND YEAR

Design Proficiencies, New Textile Economy

Design Proficiencies, New Textile Economy.

THIRD YEAR

Experiential work placement,

Advance Design, Applied sustainable design solutions.

FOURTH YEAR

Synthesis, Senior collection development 


\section{CONCLUSION AND OUTLOOK}

In the field of design and merchandising education, there is a limited amount of class time to pack in lessons and concepts that challenge world views while also teaching skill development. Entrepreneurialfocused designers and merchandisers trained in ethical decision-making as part of the design process may hold the key to solving the world's most pressing issues, from climate change and health disparities to social injustices. Moving forward, the authors seek to evolve the transformative pedagogy which will include ethics and entrepreneurship using the canvas tools presented above and will conduct qualitative studies to be able to understand the students' perspectives on ethics prior to and after the course and into their early careers. The goal is to evaluate and evolve how this approach might help to prepare a new generation of transformative professionals.

\section{REFERENCES}

Bcorporation.net. (n.d.). About B Corps | Certified B Corporation. [online]. Retrieved January 29, 2021, from https://bcorporation.net/about-b-corps

Cosic, M. (2017). 'We are all entrepreneurs': Muhammad Yunus on changing the world, one microloan at a time. [online] The Guardian. Retrieved January 29, 2021 from https://www.theguardian.com/sustainable-business/2017/mar/29/we-are-all-entrepreneursmuhammad-yunus-on-changing-the-world-one-microloan-at-a-time

Definition of entrepreneur. (n.d.). In Dictionary.com. Retrieved January 29, 2021, from https://www.dictionary.com/browse/entrepreneur

Ethics for Designers. (n.d.). Ethics for Designers - About the toolkit. [online]. Retrieved January 29, 2021, from https://www.ethicsfordesigners.com/about

Keitsch, M., \& af Ornäs, V. (2016). ETHICS IN DESIGN CURRICULA - TEACHING APPROACHES. [online] Designsociety.org. Retrieved January 29, 2021, from https://www.designsociety.org/downloadpublication/39133/ETHICS+IN+DESIGN+CURRICULA+-+TEACHING+APPROACHES

Kim, S., Karlesky, M., Myers, C., \& Schifeling, T. (2016). Why Companies Are Becoming B Corporations. [online] Harvard Business Review. Retrieved January 29, 2021, from https://hbr.org/2016/06/why-companies-are-becoming-b-corporations

Matthew Manos. (n.d.). Retrieved January 29, 2021 from https://www.mattmanos.com/ Papanek, V. (2016). Design for the Real World (p.291). London: Thames \& Hudson. Unesdoc.unesco.org. (2006). Framework for the UN DESD international implementation scheme. [online]. Retrieved January 29, 2021, from https://unesdoc.unesco.org/ark:/48223/pf0000148650

Vucetich, J., \& Nelson, M. (2010). Sustainability: Virtuous or Vulgar? BioScience, 60(7), 539-544.

West, R. (2016). Breaking Down Walls to Creativity Through Interdisciplinary Design. Educational Technology, 56(6), 47-52.

\section{APPENDIX}

TABLE 1

\section{PLAN OF STUDY FOR TRANSDISCIPLINARY FASHION EDUCATION EXPERIENCE}

\begin{tabular}{l}
\hline Transdisciplinary Course Plan \\
\hline First Year: Global Challenges and Responsible Practice in Fashion \\
\hline Introduction to the fashion industry through a guest speaker series with industry innovators and disruptors, \\
assigned readings and documentaries, visits to design studios and retail locations, and interactive group \\
research and exploration. Students will create a Sustainable Fashion Reference Book detailing industry \\
terminology, eco-ethical research and data, and guest speaker/highlighted business profiles. The final \\
\hline
\end{tabular}




\begin{tabular}{|l|l|}
\hline $\begin{array}{l}\text { project will emphasize out-of-box thinking to brainstorm solutions to some of the industry's biggest } \\
\text { challenges. }\end{array}$ \\
\begin{tabular}{|l|l|} 
Course Learning Objectives & Assessments \\
Examine product life cycle, consumer culture and & Reference Book, Small Group Assignments, \\
and Quizzes
\end{tabular} \\
\hline $\begin{array}{l}\text { Investigate the ecological and ethical challenges and } \\
\text { considerations of the production cycle, and the } \\
\text { importance of social responsibility. }\end{array}$ & $\begin{array}{l}\text { Reference Book, Small Group Assignments, } \\
\text { Quizzes, Group Project }\end{array}$ \\
\hline $\begin{array}{l}\text { Critically examine the industry's role and } \\
\text { responsibility in the business of fashion. }\end{array}$ & $\begin{array}{l}\text { Small Group Assignments \& Quizzes, Group } \\
\text { Project }\end{array}$ \\
\hline Transformative Pedagogy & $\begin{array}{l}\text { Activity } \\
\text { Ethics }\end{array}$ \\
\hline Social Entrepreneurship & $\begin{array}{l}\text { Panel Discussions and Q\&A sessions with fashion } \\
\text { innovators and disruptors }\end{array}$ \\
\hline Experiential & $\begin{array}{l}\text { Engage with city-based fashion brands have a focus } \\
\text { on social impact (river clean-ups, community } \\
\text { outreach, etc.) }\end{array}$ \\
\hline
\end{tabular}

TABLE 2

\section{PLAN OF STUDY FOR TRANSDISCIPLINARY FASHION EDUCATION EXPERIENCE}

Second Year: The Future of Fashion Textiles

Examine the textile manufacturing industry and the fundamental processes involved in producing natural and man-made fabrics. Includes basic terminology and production processes as well as selection and evaluation of fabrics based on aesthetics, performance and care characteristics. Emphasis will be placed on understanding ecological and ethical challenges and considerations as well as textile innovations.

\begin{tabular}{|c|c|}
\hline Course Learning Objectives & Assessments \\
\hline $\begin{array}{l}\text { Define textile terminology, understand the textile } \\
\text { production process, and discover the uses and } \\
\text { benefits of various knit and woven fabrics. }\end{array}$ & Reference Book, Assignments, and Quizzes \\
\hline $\begin{array}{l}\text { Examine the inherent characteristics, benefits and } \\
\text { shortfalls, and ecological and ethical considerations } \\
\text { of manmade and natural fibers. }\end{array}$ & $\begin{array}{l}\text { Reference Book, Assignments, Quizzes, Topic Lead } \\
\text { Discussion, and Group Project }\end{array}$ \\
\hline $\begin{array}{l}\text { Research biotextiles and forward-thinking } \\
\text { technologies, and experiment with practical } \\
\text { applications in fashion }\end{array}$ & Lab Experiments and Group Project \\
\hline Transformative Pedagogy & Activity \\
\hline Ethics & Read excerpts from "Empire of Cotton" \\
\hline Social Entrepreneurship & Reinvention using Healthy Material \\
\hline Experiential & $\begin{array}{l}\text { Tour an urban regenerative farm that grows flax for } \\
\text { textile production that is used by city-based brands }\end{array}$ \\
\hline
\end{tabular}


TABLE 3

PLAN OF STUDY FOR TRANSDISCIPLINARY FASHION EDUCATION EXPERIENCE

\section{Third Year: Strategic Design and Merchandising}

A fully integrated experience in which design and merchandising students form groups to simulate the launch of a B Corp Fashion Brand. Circular and responsible practices will be investigated in the designing and development of garment prototypes, and each group will bring a fully merchandised collection from item selection through production to retail in an ideal Vertical Merchandising System. Forecasting, collection development, production and revisions, allocation of inventory, coordinated visual presentation packaging and problem solving of anomalies in the supply chain are integrated into this course alongside ethical and ecological principles.

Course Learning Objectives

Assessments

Explore the key elements that define brand identity Brand Strategy Presentation, Team

by exploring industry leaders, and examine how Collaboration, and Final Project

market research, brand aesthetic, analytics and corporate vision are synthesized to build a certified B Corporation.

Develop, assort and allocate a product line through defining allocating design, merchandising, Brand Strategy Presentation, Assortment and production and marketing roles and performing the following steps: Forecasting, Textile Research, Product Development, Design Adoption, Pricing and Promotion.

Examine how product is strategically, ethically and ecologically designed and developed through research, experimentation, and collaboration and produce saleable garments that match the brand vision.

Summarize retail opportunities utilizing images, data visualization, and analytics. Present a retail strategy achieved through functional collaboration using retail and financial terminology.

Transformative Pedagogy

Ethics

Activity

Social Entrepreneurship Design Ethics Canvas

Experiential

Design and Merchant Plan, Target Market

Report, and Final Project

Individual Team Critique, Final Presentation Ethical Entrepreneurship Canvas and B Corporation Assessment

Interview and collaborate with city-based social entrepreneurs and execute a solution for a B corporation fashion brand. 